\title{
XXXVIII. On the errors in longitude as determined by chronometers at sea, arising from the action of the iron in the ships upon the chronometers. Communicated by John Barrow Esq. F.R.S.
}

\section{George Fisher Esq.}

To cite this article: George Fisher Esq. (1821) XXXVIII. On the errors in longitude as determined by chronometers at sea, arising from the action of the iron in the ships upon the chronometers. Communicated by John Barrow Esq. F.R.S. , Philosophical Magazine Series 1, 57:276, 249-257, DOI: 10.1080/14786442108652495

To link to this article: http://dx.doi.org/10.1080/14786442108652495

曲 Published online: 27 Jul 2009.

Submit your article to this journal ¿

Џ Article views: 2

Q View related articles ¿ 
feet!!! The bare statement of these facts will, I trust, furnish the hest comments upon this part of the "Comparative Advautages of illuminating by Gas from Oil and from Coal."

His fifth and last head, "Which is most durable in a national point of view?" is best answered by a general axiom, That that is the best source of a nation's revenue which is most lucrative, least fortuitous, and least hazardons. That oil gas should be preferred to coal gas, because it would thereby encourage the Greenland fisheries as a nursery for our fleets, is a rather strange doctrine, when we recollect that during war it is protected by law from that most disgraceful system, the impress! And we certainly have yet to learn how it can be put in comparison with the Newcastle coal trade, and that carried on along our western and southern shores. As I said in my former reply to the very same argument, I repeat my opinion, that where the former brings up one sailor, these latter sources bring up fifty.

We have now contemplated the five-point picture of oil gas, which the fanciful pen of Mr. Ricardo has presented to the reader of the Annals of Philosophy. Be assured, Mr. Editor, that in my thus attempting to hold up the mirror of truth, in order to take a fair impartial view of it, I ain as free as even $\mathrm{Mr}$. Ricardo himself from being " influenced by interested motives in seeking publicity to it." The cause of truth and of science is alone the object I am desirous to subserve: if Mr. Ricardo or any of your numerous readers should by the aid of these reflections discover that his chief points of "Comparative Advantages," highly coloured as they are, are out of all drawing, due keeping and proportion, and that, in order to make them bear out, not a few false shades have been thrown over coal gas, - then indeed shall I rest satisfied that I have neither written, nor caused you to print, in vain. Believe me, most respectfully,

Derby Brewery, March 21, 1821. Your friend,

Gro. Lowe.

XXXVII!. On the Errors in Longitude as determined by Chronometers ut Sea, arising from the Action of the Iron in the Ships upon the Chronometers. By Gzorge Fisher, Esq. Communicaled by JoHN Bakrow, Esq. F.R.S.*

T $\mathrm{H} \mathrm{E}$ determination of the longitude at sea by time-keepers, is so exceedingly easy from the simplicity of the observations and calculations employed, and from the general practicability of the method, as to render chronometers, in the present improved state of navigation, almost indispensable articles in the equipment of ships for foreign service; and I shall feel happy if the following

* From the Transactions of the Royal Society for 1820. Part II.

Vol. 57. No. 276. April 1821.

I i

oluser- 
observations may, in any way, contribute to the more accurate determination of the longitude by this method.

The sudden alteration in the rates of chronometers when taken on board of ships, has been frequently observed by intelligent seamen; and is generally ascribed to the motion of the vessels. Before, however, I attempt to account for this alteration, I shall first prove that it actually takes place; and, in order to do this, shall relate the circumstances connected with the chronometers on board the Dorothea and Trent, commanded by Capt Buchan, which occurred during the late voyage to the north pole.

Soon after the arrival of the ships on the coast of Spitzbergen, the chronometers on board the Dorothea (five in number) were found to be rapidly gaining on their former rates as determined in Loudon previous to the ships sailing; in consequence of which the land appeared considerably to the westward of its true position as determined by lunar observation, and they were found to be still gaining daily, which appeared not only from each subsequent set of lunars, but also by comparing the longitude of dif. ferent points of land determined by the chronometers, with the longitude of the same points ascertained in the same way some time afterwards.

For instance: The longitude of a remarkable point of land on the north-west coast of Spitzbergen, called Cloven Cliff, was found by a mean of the observations taken with the chronometers on June 21,1818 , to be $10^{\circ} 35^{\prime} 27^{\prime \prime} \mathrm{E}$.; but the longitude of the same point of land on July 31 , was $10^{\circ} 15^{\prime} 37^{\prime \prime} \mathrm{E}$., making a difference of no less than about $20^{\circ}$ of longitude in five weeks; that is, estimating the longitude with the same rates and errors as determined in London before their departure. From this, therefore, it appears, they had been gaining on their former rates, or had been increasing their gaining rates, and diminishing their losing ones.

An opportunity soon afterwards occurred of ohserving the effect produced upon the chronometers by removing them on shore. On the 9 th of August, the chronometers, nine in number, were landed on an island, where a temporary observatory had been erected for the purpose, and the latitude of which had been accurately determined with a repeating circle made by Troughton, when it was found that the aceeleration inmediately ceased; for the longitude of the place by chronometers, August 12, was $9^{\circ} 42^{\prime}$ $36^{\prime \prime} \mathrm{E}$. $\mathrm{but}$ on the $27 \mathrm{th}$, it was $10^{\circ} 1^{\prime} 0^{\prime \prime} \mathrm{E}$., maling a difference of $18^{\prime} 24^{\prime \prime}$ of longitude in fifteen days, using the former rates.

Since, therefore, the chronometers were getting easterly by their removal on shore, the acceleration must have ceased; which will appear upon consideration.

A similar circumstance was observed by Lieut. Franklin to take 
take place with the chronometers on board the Trent, which were four in number; and he observes, "It may be worthy of remark, that the chronometers taken out by the Hon.Capt. Phipps showed too great westerly longitude, and consequently gained on these seas. The faet of so many chronometers altering their rates the same way, is curious; but I an not aware that any cause can be assigned."

The effect produced upon one or two of the chronometers by their removal to land, was very remarkable; a chronometer made by Baird was (by observations taken on shore near where the ships lay at anchor, by Lieutenants Franklin and Beechey, with false horizon, and eight-inch reflecting circles of Troughton, from August 8 A.M. to 12 P.M.) losing $3^{* 4} 4$ daily when on board; but upon its removal on shore to the observatory, its rate per transit, from Angust 16 to 26 , was observed by myself to be $18 . " 2$ losing. Upon again removing it on board, it was found by observation, as before, to be losing $6 . " 5$ daily; from which it appears the chronometer lost no less than about thirteen or fourteen seconds daily by its removal on shore.

Another chronometer in the Trent, made by Pennington, had been gaining rapidly on board; when taken on shore, it acquired immediately a losing rate of $1 . " 8$, nearly the same as it had in London before the vessels sailed.

A chronometer of my own, by Arnold, was affected likewise nearly as much, losing about $9^{\prime \prime}$ daily by its removal on shore.

In the other chronometers the alteration was less sudden, but was ultimately not less considerable; and they were several days on shore before they acquired a steady rate, as will appear by the following table of their rates, during the interval of the respective dates.

Table of Rates of Chronometers immediately when landed, August 9, 1818.

\begin{tabular}{|c|c|c|c|c|c|}
\hline & $\begin{array}{c}\text { No. 1. } \\
\text { Earnshaw. }\end{array}$ & $\begin{array}{c}2 . \\
\text { Arnold. }\end{array}$ & $\begin{array}{c}4 . \\
\text { Barraud. }\end{array}$ & $\begin{array}{c}5 . \\
\text { Arnold. }\end{array}$ & Clock. \\
\hline August 9 & $+12 \cdot 0$ & -0.2 & $+"{ }^{\prime \prime} \cdot 1$ & $-33 \cdot 5$ & \\
\hline 11 & $+10 \cdot 2$ & 0. & $+7 \cdot 9$ & $-34 \cdot 2$ & \\
\hline 12 & +7.98 & $-1 \cdot 85$ & +0.8 & $-36 \cdot 2$ & $+70 \cdot 60$ \\
\hline 16 & +6.2 & $-5 \cdot 1$ & $+7 \cdot 1$ & -40.9 & $+69 \cdot 03$ \\
\hline 20 & +5.63 & $-5 \cdot 2$ & +28 & $-37 \cdot 7$ & $+69 \cdot 12$ \\
\hline $\begin{array}{l}23 \\
26\end{array}$ & +4.02 & $-6 \cdot 1 \frac{1}{x}$ & $+4 \cdot 3$ & -41.5 & $+69 \cdot 29$ \\
\hline
\end{tabular}


The rates from August 12 to 26, were determined by the sun's transit, and those from August 9th (the day on which the chronometers were landed) to the 12 th, by a comparison with the clock, supposing its mean rate $+69^{\circ}$ "5, as no observation occurred during this interval; and by this table it appears, that the chronometers when landed were rapidly diminishing their gaining rates, and increasing their losing ones. In the others the effect was almost immediate.

The clock and chronometers were likewise landed upon a small island in Fair Haven, on the north coast of Spitzbergen, on the 30 th June ; and, as the same circumstances occurred, it will be needless to detail them.

The following table is.intended to show the difference between the rates on board the ships and what they wuild have been had they been on shore.

\begin{tabular}{|c|c|c|c|c|c|}
\hline Chronometers. & $\begin{array}{l}\text { Error, } \\
\text { Greenwich time. }\end{array}$ & $\begin{array}{l}\text { Differ- } \\
\text { ence. }\end{array}$ & $\begin{array}{c}\text { Inter- } \\
\text { val. }\end{array}$ & $\begin{array}{r}\text { Mean } \\
\text { Rates } \\
\text { at Sea. }\end{array}$ & $\begin{array}{c}\text { Mean } \\
\text { Rates on } \\
\text { Shore. }\end{array}$ \\
\hline No. l. Earnshaw. & $\begin{array}{l}\text { April 11, }+7.40 \cdot 1 \\
\text { Aug. 25, }+26.32 \cdot 2\end{array}$ & $+18.52 \cdot 1$ & $\begin{array}{r}\text { days } \\
136\end{array}$ & $+8^{\prime \prime} \cdot 0$ & $+3^{\prime \prime} \cdot 8$ \\
\hline 2. Arnold. & $\begin{array}{l}\text { April } 11,-0.42 \\
\text { Aug. } 25,-4.15\end{array}$ & -3.33 & 136 & $-1 \cdot 5$ & $-5 \cdot 2$ \\
\hline 3. Arnold. & $\begin{array}{l}\text { May } 7, \quad-1.44 \\
\text { July } 2, \quad-3.36\end{array}$ & -1.52 & 56 & $-\mathbf{2} \cdot 0$ & -6.5 \\
\hline 4. Barraud. & $\begin{array}{l}\text { April 1, }-0.1 \\
\text { Aug. } 25,+5.55 \cdot 5\end{array}$ & $+5.56 \cdot 5$ & 146 & $+2 \cdot 5$ & $+1 \cdot 2$ \\
\hline 5. Arnold. & $\begin{array}{l}\text { April 15, }-0.38 \\
\text { Aug. 25, }-28.48\end{array}$ & -28.10 & 132 & $-12 \cdot 8$ & $-22 \cdot 4$ \\
\hline 6. Earnshaw. & $\left|\begin{array}{l}\text { April } 11,+1.13 \\
\text { Aug. } 25,+0.2 \cdot 2\end{array}\right|$ & $-1.10 \cdot 8$ & 136 & -0.5 & -0.93 \\
\hline 7. Pennington. & $\begin{array}{l}\text { April 11, }+0.53 \\
\text { Aug. 25, }+\mathrm{J} 3.57\end{array}$ & $|+13.3 \cdot 5|$ & 136 & $+5 \cdot 8$ & -0.63 \\
\hline 8. Arnold. & $\begin{array}{l}\text { April 13, }-0.24 \\
\text { Aug. 25, }-1553.5\end{array}$ & $+16.17 \cdot 5$ & 134 & $+7 \cdot 3$ & -2.5 \\
\hline 9. Baird. & $\begin{array}{l}\text { April 15, + } 0.25 \cdot 1 \\
\text { Aug. } 25,+5.12 \cdot 5\end{array}$ & $47 \cdot 4$ & 132 & $+2 \cdot 2$ & $-5 \cdot 15$ \\
\hline
\end{tabular}

The errors of the chronometers in April, were those obtained in London before the ships sailed ; those on the 25th of August were determined at the observatory on Dane's Island, Spitzber- 
gen, the longitude of which was determined by a great many observations of the distances of the sun and moon for several days with 'Troughton's eight-inch sextants and reflecting circles. The rates in the column entitled "Mean Rates at Sea," are deduced by dividing the difference of the errors by the interval.

The rates in the column entitled " Mean Rates on Shore," or more properly what they would have had, are means between the rates of chronometers on shore before leaving England, and those obtained at Spitzbergen; and although a mean between the rates of chronometers obtained at different times, mav not accurately be the mean rate they would have had during the interval of those times, from the continued variation to which they are subject; yet, upon comparing the two last columns together, of the rates thus deduced, it will be perceived, that in all the chronometers their gaining rates had either been increased, or their losing ones diminished on ship-board, or, in other words, they had all been accelerated.

Nor is this acceleration peculiar to high latitudes ; it was observed very soon after the chronometers were put on board in the River, particularly in Nos. 3 and 8 , which, upon arriving at Shetland, were found to have gained instead of losing rates, which they had in London.

This aceeleration was very soon perceptible in the chrononeters taken out by the Hon. Captain Phipps, made by Kendal and Arnold. Mr. Lyons, who accompanied him, landed at Sheerness Fort, and found the longitude by them to be $30^{\prime} 0^{\prime \prime} \mathrm{E}$. which is about $13^{\prime} \mathrm{W}$. of the true longitude, as determined in the Trigonometrical Survey.

The same occurrenee took place last summer (1819). The longitude of a place in one of the Orkney Islands, as retermined by three chronometers made by Arnold, two of them belonging to myself, the other to Lieut. E. Home, R. N., who accompanied me, was $6^{\prime} 40^{\prime \prime} \mathrm{W}$. of the longitude determined by the difference of $A R$ of stars E. and W. of D.

Again, in the trial of Mr. Harrison's time keeper, in 1764, the longitude of Barbadoes by the watch was $10^{\prime} 45^{\prime \prime}$ more to the westward than that determined by astrononical observations made by the persons sent out for that purpose.

Soon after this trial, the commissioners of longitude agreed with Mr. Kendal, one of the watchmakers appointed by them to receive Mr. Harrison's discoveries, to make another watch on the same construction, which went considerably better than $\mathrm{Mr}$. Harrison's. Mr. Kendal's watch was sent out with Captain Cook in his second voyage towards the south pole and round the world, in the years $1772-3-4$ and 5, "when the only fault 
found in the watch was, that its rate of going was continually aecelerated."

It now remains, therefore, to determine what this acceleration arises from. That it does not arise from the motion of the vessels, is evident in the case of the nine chronometers on board the Dorothea and Trent; since the acceleration was observed when the ships were firmly beset with ice; also in the case of the als teration in the rates of the chronometers upon landing, and taking them on board again at Dane's Island, the ships were riding at anchor close in shore without any perceptible motion.

An account was also kept on board and on shore, of the state of the temperature and barometer, every two hours, both night and day; and upon comparing them together, there does not appear to be the least correspondence between the change of rates and the temperature at the time.

It appears therefore to me, that this acceleration arose entirely from the magnetic action exerted by the iron in the ship on the inner rim of the balance, which is made of steel.

That the iron in the ships becomes magnetic, is plain, from the polarity which exists in it; the whole forming altogether one large magnet, having its south pole on deck nearly amidships, and its north pole below. This is seen from the constant deviation of the north end of the compasses placed on deck towards the centre of the ship, as appears from recent observations, which I have mentioned elsewhere.

Nor is it surprising that the force exerted by the ship's iron (thus become magnetical) on the balance of the chronometers, should be sufficient to cause a very sensible alteration in the rate of going, when we consider how easily, in other cases, the presence of any thing magnetical is detected by the alteration of the rate of a chronometer; and when we consider the great influence exerted by this iron upon the binuacle compasses at very considerable distances, and in situations where the utmost precaution is used to remove every piece of iron from them, by using copperbolts, fastenings, \&c.

It remains only to determine, how far this alteration in the rates of the chronometers, can be reconciled with that observed in chronometers when under the influence of magnets placed in different positions with respect to their balances.

To determine this, two watches were used, with steel balances and horizontal escapements, one by Earnshaw, the other by Allan and Caithness; also two chronometers made by Arnold. To each of these watches were applied, at a distance of two inches from the balance, magnets of twelve inches in length, in four different positions, and in the planes of the balances.

The 
The following Table will show the rates of the watches in twenty-four hours, deduced by comparing them with an excellent clock with Graham's dead beat escapement, and regulated by transit.

\begin{tabular}{|c|c|c|c|c|c|c|}
\hline & No. 1 . & No. 2. & & & No. 3. & No. 4. \\
\hline$\stackrel{N}{S}$ & $\begin{array}{r}\quad \\
+9.15 \\
+\quad 8.12\end{array}$ & $\begin{array}{r}16.0 \\
+5.0 \\
+21.0\end{array}$ & 3 & $\begin{array}{l}N \\
S\end{array}$ & $\begin{array}{l}+6.34 \\
+\quad 2.18\end{array}$ & $\begin{array}{r}+0.41 \\
+0.44\end{array}$ \\
\hline $\begin{array}{l}\mathrm{N} \\
\mathrm{S}\end{array}$ & $\begin{array}{r}+8.0 \\
+48.0\end{array}$ & $\begin{array}{l}+18.0 \\
+8.0\end{array}$ & 6 & $\begin{array}{l}N \\
S\end{array}$ & $\begin{array}{l}+1.28 \\
+5.27\end{array}$ & $\begin{array}{l}-1.43 \\
-0.36\end{array}$ \\
\hline $\begin{array}{c}\mathrm{N} \\
\mathrm{S}\end{array}$ & $\begin{array}{r}+47.10 \\
+72.0\end{array}$ & $\begin{array}{l}+17.8 \\
+8.44\end{array}$ & 9 & $\begin{array}{l}\mathrm{N} \\
\mathrm{S}\end{array}$ & $\begin{array}{l}+5.22 \\
-0.14\end{array}$ & $\begin{array}{l}+1.3 \\
+0.41\end{array}$ \\
\hline $\begin{array}{l}\mathrm{N} \\
\mathrm{S}\end{array}$ & $\begin{array}{l}+4.14 \\
-2.0\end{array}$ & $\begin{array}{l}+4.32 \\
+15.0\end{array}$ & 12 & $\begin{array}{l}\mathrm{N} \\
\mathrm{S}\end{array}$ & $\begin{array}{l}+2.47 \\
-1.2\end{array}$ & $\begin{array}{l}+1.12 \\
+1.24\end{array}$ \\
\hline
\end{tabular}

The first column in this table shows the pole of the magnet applied to the watch; the second and third, the rate or effect produced on each watch; the fourth column shows the figure on the face of the watch opposite to which the magnet was applied.

The watch, No. 1, gained with both poles, and in every position of the magnet but one. No. 2 gained with both poles in every position. Nos. 3 and 4 gained in every position but two; and the quantities lost in the positions were far exceeded by the accelerations caused by the opposite poles, excepting one case in that of No. 4.

The magnets were likewise placed in different positions out of the planes of the balances; the results were very similar to those above, but differing in quantity, according to the distance of the magnets from the planes of the balances.

Upon placing the magnets very near to the rim of the balances, a very rapid acceleration took place with both poles, and in every position of the maguets, particularly in the watches Nos. 1 and 2 . Upon too near an approach of the magnets, the watch No. 1, and chronometer No.3, were rendered useless; the former, when the magnets were taken away, gaining no less than about $1 \frac{1}{4}$ hour, and the chronometer losing about $50^{\prime \prime}$ in 24 hours; and in again repeating the experiments in the plane of the balances, the rates of the chronometers (without the magnets) were so variable, that it was necessary to determine their rates before and after each application of the magnets : the following, however, is a Table of the results upon the chronometers Nos. 3 and 4. 


\begin{tabular}{|c|c|c|c|}
\hline & No.3. & No.4. & \\
\hline $\mathrm{N}$ & $+6.22 \cdot 7$ & $+0.43 \cdot 5$ & 3 \\
$\mathrm{~S}$ & +1.24 & +0.46 & \\
\hline $\mathrm{N}$ & -5.32 & -1.40 & 6 \\
$\mathrm{~S}$ & +6.15 & -1.37 & \\
\hline $\mathrm{N}$ & +5.19 & +1.18 & 9 \\
$\mathrm{~S}$ & -1.53 & +1.12 & \\
\hline $\mathrm{N}$ & +1.59 & $+1.11 \cdot 7$ & 12 \\
$\mathrm{~S}$ & $+2.7 \cdot 3$ & +1.29 & \\
\hline & & & \\
\hline $\mathrm{N}$ & +0.31 & +1.14 & 3 \\
$\mathrm{~S}$ & +2.9 & +0.43 & \\
\hline $\mathrm{N}$ & -5.9 & -1.24 & 6 \\
$\mathrm{~S}$ & $+4.25 \cdot 7$ & -0.59 & \\
\hline $\mathrm{N}$ & +5.25 & +0.55 & 9 \\
$\mathrm{~S}$ & -1.53 & +0.42 & \\
\hline $\mathrm{N}$ & +2.33 & +1.5 & 12 \\
\hline $\mathrm{S}$ & -2.23 & +1.6 & \\
\hline
\end{tabular}

Each of these results in this Table, is the difference of the rates when the magnets were applied, and a mean of the rates of the chronometers before and after the application of the magnets. The rate of the chronometer No. 3 , is very different from that given in the former Table; that of No. 4 is nearly the same, and does not appear to have been affected, as No. 3 was, by the close approach of the magnet.

Upon the whole, however, it appears that chronometers will be generally accelerated (particularly if their balances have not received polarity by the too near approach of any thing magnetical) on ship-board. It appears probable, likewise, that the force of the balance springs is affected in the same way; since it is well known that chronometers having gold balance springs, although more difficult to adjust, yet keep better rates at sea than the others.

However this may be, these observations show the necessity of not trusting to the rates of chronometers ascertained during the 
time they are on shore; and if the rates are ascertained on board, the chronometers should always be kept in the same place, and also in the same position with respect to the ship; for I have but little doubt that, upon an accurate trial, a chronometer will be found to change its rate, more or less, according as these circumstances are attended to. If these precautions are not taken, land will appear to be considerably to the westward of its true position: this is particularly exemplified in the observations of the Hon. Captain Phipps; from which nearly the whole line of coast on the west side of East Greenland has been placed nearly $1 \frac{I^{\circ}}{2}$ too much to the westward, by reason of the acceleration of his chronometers : the same circumstance would have occurred with the chronometers in both of the ships Dorothea and Trent, in the late voyage, had not the longitude been otherwise determined. It is therefore highly requisite that attention should be paid to a circumstance so much connected with the improvement of geography as well as the safety of the seaman.

The foregoing paper is followed by an Appendix containing Tables of Rates furnished by Mr. Coleman, teacher of navigation, and embrace observed rates in different voyages from 1802 to 1820 inclusive, corresponding very much with $\mathrm{Mr}$. Fisher's, and tending to confirm his general inferences.

XXXIX. Sequel of the Experiments on the Action of the Voltaic Pile upon the Magnetic Needle. By M. Borsgeraud Jun.

[Concluded from p. 206.]

1

THIN it useful to make known an illusory phænomenon which the Voltaic apparatus I made use of presented. I took a very fine silk thread; I attached it to a fixed point by a small particle of wax. I took another very small particle of wax, which I fixed to the other end of the thread, in such a manner as to form a pendulum with it. I afterwards pressed the latter piece of wax on one of the poles of a magnetised steel wire which remained suspended. The other pole was rubbed with a little grase, so that I could make adhere to it horizontaliy a small needle of Spanish wax or silver. This arrangement, it will be observed, has some analogy with the electroscope of Coulomb. The object of it was to indicate the action of the conducting wire on the faces of the needle. The following are the deceptive phænomena which it presents.

A magnetised bar which I held in my hand appeared constantly to attract, by its north pole, the south face of the suspended needle; the south pole appeared equally to attract the Vol.57. No. 276. April 18\%1. K k north 